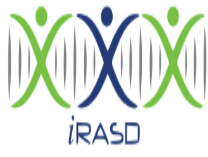

iRASD Journal of Management

Volume 3, Number 3, 2021, Pages 360 - 372

Journal Homepage:

https://journals.internationalrasd.org/index.php/jom

\title{
Impact of Corporate Social Responsibility on profitability of banks in Pakistan: Application of GMM Approach
}

\author{
Mehreen Nazish ${ }^{1}$, Muhammad Hanif Akhtar ${ }^{2}$ \\ ${ }^{1} \mathrm{PhD}$ Scholar in Social Sciences, (Business Administration), Bahauddin Zakariya University, Multan, Pakistan. \\ Email: mehreen.nazish12345@gmail.com \\ 2 Professor and Chairman, Department of Commerce, Bahauddin Zakariya University, Multan, Pakistan. \\ Email: haneefakhtar@bzu.edu.pk
}

ARTICLE INFO

Article History:

Received:

Revised:

Accepted:

04, 2021

December 29, 2021

December 30, 2021

Available Online: December 31, 2021

\section{Keywords:}

Corporate social responsibility

Profitability

Commercial banks

Panel data

GMM

Pakistan

\section{Funding:}

This research received no specific grant from any funding agency in the public, commercial, or not-for-profit sectors.

\section{ABSTRACT}

The present study investigates the effects of corporate social responsibility (CSR) on financial performance of commercial banks in Pakistan employing the generalized method of moments (GMM) estimator on a panel data. A diverse sample of 25 banks is selected for the analyses for a period of 11 years (2010-2020) based on consistently available data. In addition to the CSR index, some bank-specific and macroeconomic variables are used as control variables to test for the effects of CSR initiatives on profitability of banks in Pakistan. Our findings demonstrate that the CSR drives and commitments on social expectations reward the banks with larger profit margins. Consequently, the results tend to validate the stakeholder theory where socially responsible enterprises lead towards greater financial performance. The control variables like capital intensity, credit risk, bank size, liquidity, age of the bank, proportion of non-executive directors, tangibility and GDP growth divulge mixed results. The diversity in results propose a number of policy and managerial implications both for policy makers and banks managers.

OPEN

ACCESS

(C) 2021 The Authors, Published by iRASD. This is an Open Access article under the Creative Common Attribution Non-Commercial 4.0

Corresponding Author's Email: haneefakhtar@bzu.edu.pk

Citation: Nazish, M.., \& Akhtar, M. H. (2021). Impact of Corporate Social Responsibility on profitability of banks in Pakistan: Application of GMM Approach. IRASD Journal of Management, 3(3), 360-372. https://doi.org/10.52131/jom.2021.0303.0051

\section{Introduction}

The ever-growing concept of corporate social responsibility (CSR) was initially coined by Bowen and Johnson (1953). The fundamental question he raised and remains to be asked, "what are the responsibilities to society may businessmen reasonably be expected to assume?" The CSR is more closely associated with corporate philanthropy and social initiatives that are perceived to be the heart and soul of business (Levy, 1999). He further espouses that the social activities ought to be in line with business objective of profitability (heart) and need to articulate the ideals of helping society (soul). In addition to financial goals, the CSR has been conceived as pursuit of environmental and social ambitions engaging various stakeholders.

Hence, CSR has been debated over the years with a special stress on the benefits it contributes towards financial performance of firms. However, it remains contentious in terms of its contribution and potential gains for the corporate world. Many of the researchers tend to claim a positive link between the CSR vis-à-vis financial performance of 
firms while the others assert either towards a negative association or no connection at all ${ }^{1}$. However, the idea remains relatively less explored in the case of commercial banks in Pakistan as these are generally involved in CSR activities. Hence, the primary objective of this paper is to analyze the fact if banks in Pakistan pursuing CSR-based policies end up with higher level of profitability compared to those that do not. The study is an attempt to fill this gap.

Pakistani financial sector offers a vibrant and diversified banking system in the country. This includes a variety of both local and foreign banks in the country. Among the local banks, there is further diversification in terms of Islamic and conventional counterparts which offer a variety of banking products to both the retail and corporate clients. The conventional banking part being the oldest still stands as the largest, yet the Islamic banking segments has also grown phenomenally. Despite the pandemic situation and global economic slowdown, the financial year of 2020 proved to be a promising one for the banking sector. The profits increased by $31 \%$ and $38 \%$ respectively for the conventional and Islamic banks (KPMG, 2021). Increase in investments in government securities supported asset growth in the banking sector, even though the recession in economy reduced the credit to private sector. Deposit growth was the outcome of constrained spendings by consumers under the Covid-19 conditions. The capital adequacy ratio (CAR), being at $18.6 \%$, remained higher than the regulatory requirement of $11.5 \%$. As a blessing in disguise, the Covid-19 helped in generating higher returns for the banks through the adoption of online banking activities. Given the fact that banks are consistently contributing to CSR spillovers taking the form of educational scholarships, donations, charity, spendings on health etc., this makes a case to explore the fact as to how the CSR pursuits tend to contribute towards profitability of banks in Pakistan.

The paper adds on to the existing empirical investigations in many ways. Firstly, the extant literature has mainly focused on CSR practices of financial firms in countries other than Pakistan. The paper extends the discussion towards Pakistani banks in context of the impact of CSR activities on their financial performance. A panel data analyses based on Generalized Method of Moments (GMM) is conducted for 25 banks in Pakistan from 2010 to 2020. Secondly, in addition to the CSR practices by the banks in Pakistan, the present research has also assessed the impact of non-CSR factors, both being bank-specific vis-àvis macroeconomic ones. Thirdly, using GMM approach for the data analysis, the investigator can overcome the issues of potential endogeneity, heterogeneity, and autocorrelation in the analyses.

Rest of the discussion is organized as follows. Section 2 provides an overview of the contextual studies and the variables on CSR and bank performance in Pakistan. Section 3 illustrates the methods and materials used in the research. Section 4 discusses empirical outcomes while Section 5 concludes with managerial and policy implications.

\section{Theoretical Underpinnings}

Several studies have sought arguments in favor of CSR while the findings remain mixed. Some of the studies have discovered a positive effect of CSR on profitability while others have found a negative one, while others found no relationship (Margolis \& Walsh, 2001; Orlitzky, Schmidt, \& Rynes, 2003; Peloza, 2009). The differences in results might have been the outcome of heterogeneity in measurement of variables, error in the model used, and a failure to deal with the problem of endogeneity. A brief review of the extant literature is presented in table-1 below.

\section{Methods and Materials}

The methodology of the study encompasses a three-stage approach: (i) data collection on CSR activities and control variables that are perceived to be important as determinants of bank profitability (ii) analysis and examination of descriptive statistics and correlation analyses between the proposed variables for the research (iii) estimation of a GMM model

\footnotetext{
${ }^{1}$ The details are provided in discussion of results.
} 
to examine the impact of CSR and control variables on profitability of banks. Further details are given below.

Table 1

Literature Review of the Variables Used in the Model

\begin{tabular}{|c|c|c|c|c|}
\hline Variables & Dependent Va & $\begin{array}{l}\text { Sign } \\
\text { able }\end{array}$ & Proxies & Technique used \\
\hline $\begin{array}{lll}\text { Net } & \text { Profit } & \text { Margin } \\
(\text { NPM) } & & \end{array}$ & $\begin{array}{l}\text { Demirgüç-Kunt and Huizinga (1999); } \\
\text { Lin, Chang, and Dang (2015); Moore } \\
\text { (2001); Tan (2016); Yao, Haris, and } \\
\text { Tariq (2018). }\end{array}$ & $\begin{array}{l}+ \\
+\end{array}$ & $\begin{array}{l}\text { Profit after tax/ } \\
\text { Revenue }\end{array}$ & \\
\hline \multicolumn{5}{|c|}{ Independent Variables } \\
\hline CSR Index & $\begin{array}{l}\text { Haniffa and Hudaib (2007); Kludacz- } \\
\text { Alessandri and Cygańska (2021); } \\
\text { Maali, Casson, and Napier (2006). }\end{array}$ & $\begin{array}{l}+ \\
-\end{array}$ & $\begin{array}{l}\text { Global Reporting } \\
\text { Initiative (GRI). } \\
\text { Includes the GRI } \\
\text { Profile and Index, GRI } \\
\text { Indicators, and GRI } \\
\text { Principles. } \\
\text { CSR adoption is } \\
\text { measured by a dummy } \\
\text { variable. } \\
\text { CSR investment in } \\
\text { monetary values } \\
\text { converted into natural } \\
\text { logarithms form. }\end{array}$ & $\begin{array}{l}\text { Panel and } \\
\text { hierarchical } \\
\text { regression models } \\
\text { GMM }\end{array}$ \\
\hline Capital intensity (KI) & $\begin{array}{l}\text { Pasiouras and Kosmidou (2007); } \\
\text { Pham, Dao, and Nguyen (2021). }\end{array}$ & + & Equity/ Assets & GMM \\
\hline Credit risk (CR) & $\begin{array}{l}\text { Adusei (2015); Ali and Puah (2018); } \\
\text { Phan, Anwar, Alexander, and Phan } \\
\text { (2019). }\end{array}$ & + & $\begin{array}{l}\text { Total loans } \\
\text { outstanding as a } \\
\text { percentage of total } \\
\text { assets }\end{array}$ & GMM \\
\hline Firm size (LTA) & $\begin{array}{l}\text { Adusei (2015); Ali and Puah (2018); } \\
\text { Batir, Volkman, and Gungor (2017); } \\
\text { Kohlscheen, Murcia Pabón, and } \\
\text { Contreras (2018); Pham et al. } \\
\text { (2021). }\end{array}$ & $\begin{array}{l}+ \\
-\end{array}$ & Ln (Assets) & GMM \\
\hline Liquidity (LIQD) & $\begin{array}{l}\text { Derbali (2014); Goddard, Liu, } \\
\text { Molyneux, and Wilson (2013); } \\
\text { Mehari and Aemiro (2013); Tan } \\
\text { (2016). }\end{array}$ & - & $\begin{array}{l}\text { Current assets / } \\
\text { current } \\
\text { liabilities }\end{array}$ & $\begin{array}{l}\text { Panel data } \\
\text { estimation model }\end{array}$ \\
\hline Age of the Firm (Age) & $\begin{array}{l}\text { Chun, Kim, Morck, and Yeung } \\
\text { (2008); Mallinguh, Wasike, and } \\
\text { Zoltan (2020). }\end{array}$ & + & $\begin{array}{l}\text { Firm's duration since } \\
\text { inception or date of } \\
\text { merger or acquisition. }\end{array}$ & $\begin{array}{l}\text { OLS regressions } \\
\text { SEM equations }\end{array}$ \\
\hline Tangibility (TANG) & $\begin{array}{l}\text { Akintoye (2009); Derbali (2014); } \\
\text { Mehari and Aemiro (2013) }\end{array}$ & $\begin{array}{l}+ \\
-\end{array}$ & $\begin{array}{l}\text { Total fixed assets / } \\
\text { total } \\
\text { Assets }\end{array}$ & $\begin{array}{l}\text { Panel data } \\
\text { estimation model }\end{array}$ \\
\hline $\begin{array}{ll}\text { Ratio of } & \text { non- } \\
\text { executive to total } \\
\text { members (NE) }\end{array}$ & $\begin{array}{l}\text { Levrau and van Den Berghe (2007); } \\
\text { Van Ees, van der Laan, and Postma } \\
\text { (2008) }\end{array}$ & + & $\begin{array}{l}\text { No of Independent } \\
\text { non-executive } \\
\text { directors divided by } \\
\text { total directors. }\end{array}$ & SPSS Matrix \\
\hline GDP growth (GDPG) & $\begin{array}{l}\text { Athanasoglou, Brissimis, and Delis } \\
\text { (2008); Dietrich and Wanzenried } \\
(2011) \text {; Sinha and Sharma (2016); } \\
\text { Yao et al. (2018). }\end{array}$ & + & GDP growth rate & GMM \\
\hline
\end{tabular}

\subsection{Data and the Model}

The yearly data on bank-specific variables, being in thousands of rupees, was taken from annual reports of State Bank of Pakistan (SBP, Various Issues) for the period 2010 to 2020. This included a sample of 25 banks in Pakistan while some of the banks were excluded from the analysis as these were specialized banks ${ }^{2}$. The data on macroeconomic factors like GDP growth was extracted from the World Development Indicators (WDI, 2018) of the World Bank. Purposive sampling technique was used for the sample selection since

\footnotetext{
2 These included the Industrial Development Bank Ltd., SME Bank Ltd., The Punjab Provincial Cooperative Bank Ltd., and Zarai Taraqiati Bank Ltd. (ZTBL). 
the data was to be extracted for all the banks which were involved in CSR activities based on consistent availability of data for the whole period of analysis. The data were analyzed through the E-Views by using a panel Generalized Method of Moments (GMM).

\subsection{Generalized Method of Moments}

Given the form of panel data used in the study, a generalized method of moments (GMM) estimator suggested by Arellano and Bover (1995) is used. The GMM is advantageous as it helps to control for the issues of undetected heterogeneity and endogeneity (Arellano, 2002). The GMM estimator accounts for unobserved heterogeneity and persistence of dependent variable. Hence, this estimator produces consistent evaluations of parameters. The calculated coefficients appear to be more efficient since an appropriate set of instruments is applied. The system GMM estimator employs lagged value of the dependent variable both in levels and differences. The trailed values of additional regressors tend to possibly deteriorate through endogeneity as instruments.

\section{Table 2}

\begin{tabular}{ll} 
Description of Variables & Expected sign \\
\hline Variable & Description \\
\hline Net profit margin (NPM) & $\begin{array}{l}\text { The use of NPM as a measure of firm performance is advantageous as } \\
\text { it tends to consider the impact of tax expenses on bank profitability. } \\
\text { This is used as the ratio of net income to sales. }\end{array}$
\end{tabular}

\begin{tabular}{|c|c|c|}
\hline \multicolumn{3}{|c|}{ Independent variables } \\
\hline CSR index (CSRI) & $\begin{array}{l}\text { In context of the stakeholder theory, socially responsible enterprises } \\
\text { lead towards greater financial performance (FP). } \\
\text { CSR index is calculated as a proxy for CSR activities. The formula used } \\
\text { to calculate index is } \\
\qquad C S R I_{i}=\frac{\sum_{t=1}^{n} X_{i}}{n} \\
\text { This is based on categorical variables that take the value of " } 1 \text { " if the } \\
\text { firm is taking CSR initiatives, and " } 0 \text { " otherwise. }\end{array}$ & +ive \\
\hline Capital intensity (KI) & $\begin{array}{l}\text { A measure of capital intensity of banks, used as the ratio of equity to } \\
\text { total assets. }\end{array}$ & +ive / -ive \\
\hline Credit risk (CR) & $\begin{array}{l}\text { A proxy for credit quality or credit risk for the banks. } \\
\text { This is calculated by the ratio of loans / total assets. }\end{array}$ & -ive \\
\hline Bank size (LTA) & $\begin{array}{l}\text { Measure of bank size, which provides economy-of-scale advantages } \\
\text { and better risk diversification to banks. This is quantified by log of } \\
\text { total assets of the banks. }\end{array}$ & +ive \\
\hline Liquidity (LIQD) & $\begin{array}{l}\text { Measurement the ability of banks for using their cash or "quick" assets } \\
\text { to cover liabilities. This is computed as a ratio of liquid assets / total } \\
\text { assets. }\end{array}$ & -ive \\
\hline Age of the Bank (Age) & $\begin{array}{l}\text { The number of years after the company was incorporated. } \\
\text { This is expected to reflect on experience and goodwill achieved by the } \\
\text { banks over time. }\end{array}$ & +ive \\
\hline Tangibility (TANG) & $\begin{array}{l}\text { The higher tangible assets tend to assist towards smaller costs of } \\
\text { financial distress but might end up with low profitability. This is } \\
\text { determined by the ratio of fixed assets / total assets. }\end{array}$ & -ive \\
\hline $\begin{array}{l}\text { Proportion of Non- } \\
\text { executive Directors } \\
\text { (NED) }\end{array}$ & Percentage of non-executive (NED) directors in the board. & +ive \\
\hline GDP growth (GDPG) & $\begin{array}{l}\text { Real GDP growth rate, a measure of future prospectus of market size } \\
\text { and potential of the economy. This enables the banks to lend more } \\
\text { during buoyant economic conditions. }\end{array}$ & +ive \\
\hline
\end{tabular}

As proposed by Bond (2002), the study has used lagged variables that are treated as endogenous instruments. The GMM approach applies instruments for all regressors except for those considered as exogenous. Besides, the number of lags is established through Arellano-Bond autocorrelation (AR) tests and those of overidentifying constraints (Hansen, 1982). In case the null hypothesis proposed by Hansen test is rejected, the instruments fail to encounter the desired orthogonality requirements. Furthermore, validity of moment conditions depends upon the non-existence of serial correlation in idiosyncratic 
errors. However, If the null hypothesis stands at second-order, autocorrelation $\left(\mathrm{AR}_{2}\right)$ cannot be rejected, and the moment conditions remain acceptable.

\subsection{Description of Variables}

Table 2 below displays the list of variables used with definitions and expected signs while table 3 illustrates their descriptive statistics.

Table 3

Descriptive Statistics

\begin{tabular}{|c|c|c|c|c|c|c|c|c|c|c|}
\hline & PM & CSRI & KI & CR & LTA & LIQD & AGE & TANG & NED & GDPG \\
\hline Mean & 0.34 & 0.69 & 0.51 & 6.67 & 5.65 & 32.93 & 40.32 & 11.76 & 0.53 & 3.65 \\
\hline Median & 0.03 & 0.71 & 0.07 & 0.04 & 5.52 & 0.07 & 34.00 & 0.05 & 0.55 & 4.40 \\
\hline Maximum & 29.40 & 1.00 & 9.58 & 555.95 & 9.13 & 2018.19 & 108.00 & 754.41 & 0.92 & 5.84 \\
\hline Minimum & -0.26 & 0.00 & -0.02 & 0.00 & 4.03 & 0.23 & 4.00 & 0.19 & 0.00 & 0.53 \\
\hline Std. Dev. & 2.02 & 0.28 & 1.56 & 38.70 & 1.05 & 186.93 & 24.20 & 68.31 & 0.21 & 1.83 \\
\hline Skewness & 12.25 & -1.05 & 3.91 & 11.25 & 1.33 & 8.31 & 0.92 & 9.05 & 0.00 & -0.47 \\
\hline Kurtosis & 166.42 & 3.11 & 17.59 & 151.69 & 5.20 & 77.59 & 3.10 & 92.69 & 2.44 & 1.76 \\
\hline Jarque- & 312869. & & 3136. & 259134. & 136.5 & & & & & \\
\hline Bera & 50 & 50.62 & 53 & 40 & 6 & 66919.24 & 39.21 & 95923.94 & 3.65 & 27.70 \\
\hline Probability & 0.00 & 0.00 & 0.00 & 0.00 & 0.00 & 0.00 & 0.00 & 0.00 & $\begin{array}{l}0.16 \\
145 .\end{array}$ & 0.00 \\
\hline & & 189.1 & 139.0 & & 1555. & & 11088.0 & & 0 & 1002. \\
\hline Sum & 93.68 & 4 & 1 & 1834.64 & 07 & 9056.16 & 0 & 3233.31 & 4 & 41 \\
\hline Sum Sq. & & & 668.3 & 410295. & 304.7 & 9574683. & 160527. & 1278429. & 11.6 & 913.9 \\
\hline $\begin{array}{l}\text { Dev. } \\
\text { Observati }\end{array}$ & 1116.41 & 21.66 & 1 & 10 & 8 & 00 & 80 & 00 & 3 & 3 \\
\hline ons & 275 & 275 & 275 & 275 & 275 & 275 & 275 & 275 & 275 & 275 \\
\hline
\end{tabular}

Table 4

Correlation Matrix

\begin{tabular}{|c|c|c|c|c|c|c|c|c|c|c|}
\hline & PM & CSRI & KI & CR & LTA & LIQD & AGE & TANG & NED & GDPG \\
\hline PM & 1.00 & & & & & & & & & \\
\hline CSRI & 0.13 & 1.00 & & & & & & & & \\
\hline $\mathrm{KI}$ & -0.02 & 0.19 & 1.00 & & & & & & & \\
\hline $\mathrm{CR}$ & 0.04 & 0.14 & 0.16 & 1.00 & & & & & & \\
\hline LTA & -0.02 & 0.00 & -0.37 & -0.14 & 1.00 & & & & & \\
\hline LIQD & 0.01 & 0.16 & 0.31 & 0.55 & -0.15 & 1.00 & & & & \\
\hline AGE & 0.03 & 0.02 & 0.30 & 0.03 & 0.20 & 0.13 & 1.00 & & & \\
\hline TANG & 0.02 & 0.14 & 0.23 & 0.09 & -0.13 & 0.59 & 0.14 & 1.00 & & \\
\hline NED & -0.14 & -0.04 & -0.02 & -0.14 & 0.14 & -0.11 & -0.08 & -0.07 & 1.00 & \\
\hline GDPG & 0.07 & -0.12 & -0.35 & -0.11 & 0.30 & 0.03 & 0.00 & 0.04 & 0.04 & 1.00 \\
\hline
\end{tabular}

Results of the correlation matrix, in table-4 above, signify that majority of the variables are weakly correlated. However, some of the variables tend to appear as moderately correlated but do not pose a threat of multicollinearity. These include liquidity and credit risk where the correlation stands at $55 \%$ as well as liquidity and tangibility with a correlation of 0.59 . Likewise, the variables like capital risk, LTA, NED are negatively associated with profit margin but with a weak size of the correlation.

\section{Results}

The present study is about examining the relationship of CSR with profitability represented by net profit margin taken as dependent variable. The CSR is considered as an independent variable for constructing the model in addition to rest of the variables, considered as control variables. The models for the study are as follows:

\section{Model 1}

$\mathrm{FP}_{i t}=\beta_{0}+\beta_{1} \mathrm{CSR}_{\mathrm{it}}+\beta_{2} \mathrm{KI}_{\mathrm{it}}+\beta_{3} \mathrm{CR}_{\mathrm{it}}+\beta_{4} \mathrm{LTA}_{\mathrm{it}}+\beta_{5} \mathrm{LIQD}_{\mathrm{it}}+\beta_{6} \mathrm{AGE}_{\mathrm{it}}+\beta_{7}$ TANG $_{i t}+\beta_{8} \mathrm{NED}_{\mathrm{it}}+\varepsilon_{\mathrm{it}}$

\section{Model 2}

$\mathrm{FP}_{i t}=\beta_{0}+\beta_{1} \mathrm{CSR}_{i t}+\beta_{2} \mathrm{KI}_{i t}+\beta_{3} \mathrm{CR}_{\mathrm{it}}+\beta_{4} \mathrm{LTA}_{\mathrm{it}}+\beta_{5} \mathrm{LIQD}_{\mathrm{it}}+\beta_{6} \mathrm{AGE}_{i t}+\beta_{7}$ TANG $_{i t}+\beta_{8} \mathrm{NED}_{\text {it }}$
$\quad+\beta_{9} \mathrm{GDPG}_{\mathrm{it}}+\varepsilon_{\mathrm{it}}$

$\beta_{0}$ is the constant, $\beta_{1}$ is the parameter for independent and $\beta_{2}-\beta_{9}$ are the parameters for control variables. $\varepsilon_{\text {it }}$ is the error term. 


\subsection{Net Profit Margin as the Dependent Variable}

There are various measures of firm performance, while this study has used the net profit margin (NPM) as a financial measure of firm performance (Demirgüç-Kunt \& Huizinga, 1999; Tan, 2016). The use of NPM as a measure of firm performance is advantageous in the sense that it tends to consider the impact of tax expenses on bank profitability. Furthermore, being an accounting measure, NPM is calculated on time results (Lin et al., 2015) while to identify the relationship between CSR and firm performance, the use of accounting measures is more suitable (Moore, 2001).

\subsection{Independent and Control Variables 4.2.1. Corporate Social Responsibility (CSR)}

The CSR index based on various initiatives taking the form of numerous pledges on social expectations, tends to emerge as significant. This alludes towards the fact that CSR drives and commitments on social expectations reward the banks with larger profit margins. Consequently, the results tend to validate the stakeholder theory where socially responsible enterprises lead towards greater financial performance (FP) (Donaldson \& Preston, 1995; Freeman, 2010; McGuire, Sundgren, \& Schneeweis, 1988). Investments in social responsibility initiatives can be deemed as strategic creating legitimacy, reputation, and competitive advantages (Ducassy, 2013). Additionally, the managers can judge the CSR initiatives as a source to enhance company's financial performance. Furthermore, the strategic managers are competent to satisfy the social demands without risking expectations of the stakeholders. Firms' involvement in CSR drives can be perceived as trustworthy, which, in turn, is an indicator for reliable market transactions (Jones, 1995). Hence, commitment of firms in socially responsible programs is a way out to establish trust within the firms vis-à-vis outside.

Our findings are also consistent with those by Wu, Shao, Yang, Ding, and Zhang (2020) found a significantly positive association between CSR and FP and those proposed by Min, Desmoulins-Lebeault, and Esposito (2017); Resmi, Begum, and Hassan (2018); Xu and Zeng (2016) and Le, Hoang, Wilson, and Ngo (2020). However, these are on the contrast to the findings by Kiran, Kakakhel, and Shaheen (2015) and Akinleye and Faustina (2017).

In addition to the stakeholders' pressures, there are some other inherent motivations behind CSR commitments that could be valuable to the financial firms. These might include competitive advantages taking the route of expanded market share and employee incentives. The research reveals that CSR activities not only provide benefits to the firms, rather these also tend to involve augmented costs, both one-time costs and recurrent costs coupled with the risk of CSR engagement failure. This might lead to distrust by stakeholders and a damage to the firm (McWilliams, Siegel, \& Wright, 2006; Weber, 2008).

Eccles, Ioannou, and Serafeim (2012) appears to have concluded that that it really matters to invest in CSR initiatives. Firms doing so tend to have a better financial performance, producing greater worth for all the stakeholders. On the contrary, Singh, Chen, Del Giudice, and El-Kassar (2019) claim that CSR activities appear to have a negative influence on financial performance of firms and diminish gains to the shareholder. Considering the major trends in literature where companies following the CSR initiatives appear to have a higher level of financial performance compared to those that do not.

\subsubsection{Capital Intensity (KI)}

The capital intensity variable appears to have a negative association with net profit margin. This alludes to the rationale that over capitalized banks may possibly operate in a restrained manner and might ignore the profitable openings (Goddard, Liu, Molyneux, \& Wilson, 2011). Being one of the major sources of funds for banks, equity could be costlier than deposits. A shift towards greater levels of equity might lead to an increase in capital cost of the banks. The desire to lessen their costs, puts the banks under pressure by alluring them to engage in riskier activities. The same appears to the case here with 
Pakistani banks. These results are in line with those by Goddard et al. (2011) while these are on the contrast to those of Bucevska and Hadzi Misheva (2017); Kohlscheen et al. (2018).

\section{Table 5}

Model-1: Bank Specific Factors and Profitability

Dependent Variable: NPM

Instrument specification: CSRI(-1) LEQ(-1) KI(-1) CR(-1) LTA(-1) TANG(-1) LIQD(-1) LEVER(-1) DG(-1) AGE NED C

\begin{tabular}{lllll}
\hline Variables & Coefficient & Std. Error & t-Statistic & Prob. \\
CSR index (CSRI) & 3.967643 & 1.650997 & 2.403180 & 0.0170 \\
Capital intensity (KI) & -0.314350 & 0.140209 & -2.242014 & 0.0259 \\
Credit risk (CR) & -0.012277 & 0.001820 & -6.746218 & 0.0000 \\
Bank size (LTA) & -0.295103 & 0.158238 & -1.864929 & 0.0634 \\
Liquidity (LIQD) & 0.002799 & 0.000948 & 2.953210 & 0.0035 \\
Age of the banks (Age) & 0.010199 & 0.004004 & 2.547161 & 0.0115 \\
Tangibility (TANG) & -0.005954 & 0.001857 & -3.207071 & 0.0015 \\
Proportion of Non-executive & & & \\
Directors (NED) & -0.989157 & 0.346848 & -2.851845 & 0.0047 \\
C & -0.434675 & 1.232351 & -0.352720 & 0.7246 \\
J-statistic & 0.477369 & Cross-sections included 25 & \\
Prob(J-statistic) & & Total panel (balanced) & \\
\hline
\end{tabular}

\subsubsection{Credit Risk (CR)}

The credit risk emerges with a negatively significant association with profitability measure. This tends to validate the proposition that the banks with higher credit risk end up with lower profitability which arises due to lesser capitalization (Liu \& Wilson, 2010). This might also be an outcome of imprudent lending practices or aggressive behavior by banks to augment their market share while they are ready to accept the trade-off between high credit risk and lower margins. This result is in line with the findings by Williams (2007) which reveal a negative connection between credit risk and profitability and with those by Athanasoglou et al. (2008).

\subsubsection{Bank Size (LTA)}

Bank size is anticipated to provide economies-of-scale advantages and better risk diversification to banks while the expected sign is positive. However, our findings are converse to the expectations as the bank size has a negative association with profitability. This could be for the reason that banks in the sample might have achieved economies of scale up to a certain level. Having reached this point, a further growth in size may lead to decrease in profitability due to diseconomies of scale. This also upholds the notion that smaller banks can be managed easily and efficiently, leading to higher shareholder value. Our findings are consistent with the studies by Athanasoglou et al. (2008) while these are on the contrast to those by Wagner (2010).

\subsubsection{Liquidity (LIQD)}

Maintaining an appropriate level of liquidity is important for the banks as low levels of liquidity lead towards bank failures (Athanasoglou et al., 2008). In the case of high-risk loans, there is a probability that the loan losses might generate lower returns. On the contrary, lower levels of liquidity might also have a negative connection with bank profitability. Thus, there stands a need for astute risk management system by the banks.

Adequate liquidity levels tend to allow banks to entertain their liabilities without compromising on default. A greater loan to assets ratio alludes towards the lower liquidity level while the large loan volume generates greater interest revenue. These results are consistent with the findings of Athanasoglou et al. (2008); Berger and Humphrey (1994); Bourke (1989) who contend that banks with higher liquidity levels end up with higher profitability. However, these results disagree with the findings by Molyneux and Thornton (1992) as a higher volume of loans is expected to bring a decline in bank profitability if the bank does not have a good risk management system. 


\subsubsection{Age of Bank (Age)}

The existing theoretical strands proclaim that older firms are in a better position to easily acquire resources over time (Autio, 2018). As the firm grows older, it acquires greater experience, extended information, better reputation, and better approach to business networks and financial institutions. These, in turn, will help the firms to overcome limited access to resources and manage efficiently (Curran, Jarvis, Blackburn, \& Black, 1993). Studies that investigate the association between firm age and profitability have generated blended outcomes. While some of these find that age and profitability are connected negatively, others, such as Claver, Molina, and Tarí (2002) and Ito and Fukao (2006), did find a positive and significant relationship between them.

Based on this theoretical background, age is computed by the number of years since its inception. Our results reveal that age of the bank is positively and significantly associated with profit margin. The findings indicate that older banks tend to be more profitable as compared to their older counterparts and are in line with the findings by Autio (2018); Claver et al. (2002); Ito and Fukao (2006); Yazdanfar (2013).

\subsubsection{Tangibility (TANG)}

The tangible assets of banks may comprise of assets e.g., land, buildings, equipment and ATMs etc. It is perceived that the banks with larger investment in tangible assets might end up with lower costs of financial distress as compared to their counterparts investing largely on intangible assets (Akintoye, 2009). However, by spending more on intangible assets, the banks would have less liquidity at their disposal for investment on loans and advances, being their major business. Consequently, the bank profitability might be affected negatively. The findings reveal that asset tangibility has a negatively significant link with the bank profitability and are validated by Pushner (1995); Weill (2008); Zeitun and Tian (2014). This result alludes to the possibility that banks in Pakistan are either investing heavily in tangible assets or might not be using their assets efficiently. The findings are on the contrast with those by Mehari and Aemiro (2013).

\subsubsection{Proportion of Non-executive Directors (NED)}

The non-executive members on the board of directors (BOD) are one of the pillars of good governance. The non-executive directors are also deemed to be a guarantee of integrity and accountability of the boards. These members are defined as independent directors who have no affiliation with the firm except for their directorship (Clifford \& Evans, 1997). It is expected that the board members with significant outside directors will take broad-based independent decisions compared to those dominated by insiders.

The need of independent non-executive directors on the board is further validated by agency theory which states that given the separation of ownership from control, managers would opt to pursue their own goals at the expense of shareholders (Jensen \& Meckling, 1976). Thus, existence of NEDs on the board, would help to monitor and regulate the devious behavior of management and help banks towards better management that will result into higher profitability. However, the results are converse to those expected. This reveals the possibility of NEDs having some associations (friends and family members) with the executive directors of the board implying that they are not independent in reality. This study alludes towards a negative association between the number of non-executive directors and profit margin as per findings by Bhagat and Bolton (2008). It implies that greater the number of non-executive directors on the board, lower the firm performance. It shows that the larger proportion of non-executive members on the board could delay the decision-making process and impact profit margins negatively.

\subsubsection{GDP Growth (GDPG)}

There exists a mixed approach on relationship between GDP growth and bank profitability. A group of investigators contend that the GDP growth has a positive impact on bank profitability since appetite for lending intensifies during cyclical turnarounds (Athanasoglou et al., 2008; Bikker \& Hu, 2002; Demirgüç-Kunt \& Huizinga, 1999). On the 
contrary, another school of thought asserts that GDP growth rate has a negative impact on bank profitability (Tan \& Floros, 2012). The higher economic growth ameliorates the business environment attracting entry of new banks in the system which, in turn, stifles bank's profitability through increased competition. GDP growth indicates the negatively significant association with profit margin. The negative impact of GDP growth on bank profitability might be due to consistently lower growth rates of the economy during the period of analysis. Hence, the result supports the assertion of Tan and Floros (2012).

\section{Table 6}

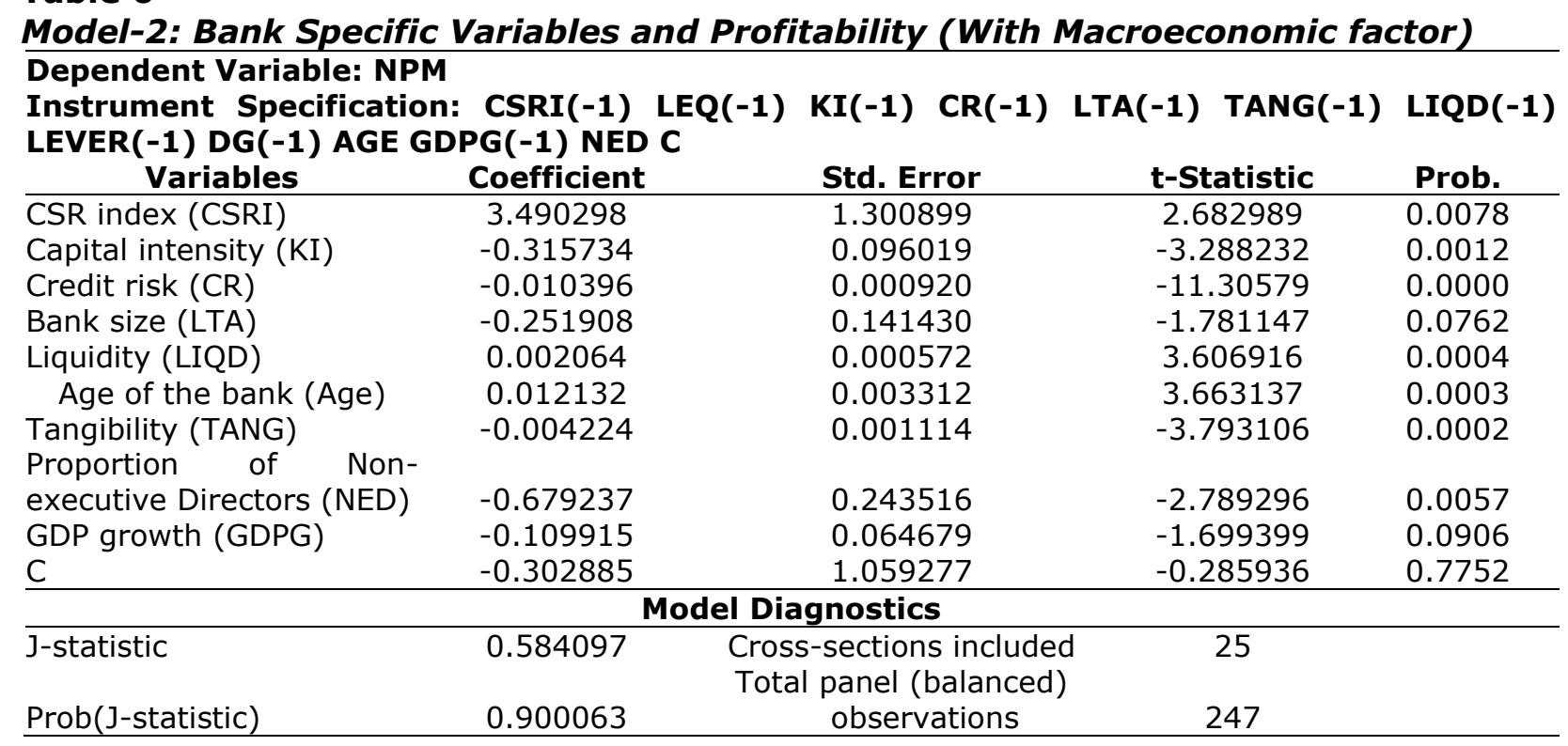

\section{Conclusions, Implications, and Agenda for the Future}

The present study discloses that most of the sampled public and private banks have been spending on CSR activities which reveals a significant impact on profitability of banks. Our results suggest that the banks pursuing CSR-based policies tend to receive a spillover effect in their profitability. Findings on the control variables have remained mixed. Factors like capital intensity, credit risk, bank size, proportion of non-executive directors, tangibility and GDP growth tend to end up with negative signs while those on liquidity and age of the bank reflect a positive support to the profitability drive. However, one might not get the impression here that the CSR expenditure alone is responsible for the enlarged profitability of banks in the sample, rather the managers need also to contemplate the role of other factors tested as control variables in this research. This implies that in the contemporary business world, society needs not only competing organizations' products and services but also the social amenities and value-added services from these organizations. The study offers some useful implications both for policy makers and managers of banks in Pakistan which are listed below.

1. To the best of authors' knowledge, there exists no regulation in Pakistan both on federal and provincial levels to make the banks responsible to spend a certain amount on CSR activities. A regulatory agency needs to be established for monitoring compliance on the CSR framework by these organizations. A regulatory framework is also needed to make disclosure on CSR expenses as mandatory for all the banks.

2. To declare the CSR-oriented expenditures as deductible from income of the banks, and to lighten the net tax liability of CSR-compliant organizations, essential regulations are required. This might encourage the banks to make adequate provisions for CSR-related pursuits, as well as for appropriate disclosure of the same.

3. Both the capital intensity and credit risk factors reflect the possibility for banks to engage in riskier activities. Such drives need to be restrained by rationalizing equity structure and aggressive lending behavior of banks.

4. The negative sign on NED variable alludes towards the possibility of NEDs having some associations (friends and family members) with the executive directors of the board implying that they are not independent. Thus, existence of non-affiliated NEDs 
on the board, would help to monitor and regulate the devious behavior of management and assist banks towards better management and higher profitability.

5. The evidence on tangibility signifies the possibility that either banks in Pakistan appear to be investing heavily on tangible assets or they might not be using these assets efficiently. The banks need to focus on these areas to generate better revenue.

6. In a macroeconomic context, GDP growth rate of the economy needs to be accelerated so that lending rates could intensify during the upward cyclical turnarounds.

Having been confined to study the effects of CSR-related expenses on profitability of banks in Pakistan, our findings propose to initiate comparative investigations to analyze the nexus between CSR and firm performance in other sectors of the economy. The future studies could incorporate additional macro-economic variables in addition to the GDP growth. The future research could also be extended to a multi-country analysis of commercial banks. This would ensure a broader understanding of the impact assessment of CSR initiatives on bank performance internationally.

\section{Conflict of Interests/Disclosures}

The authors declared no potential conflicts of interest w.r.t the research, authorship and/or publication of this article.

\section{References}

Adusei, M. (2015). The impact of bank size and funding risk on bank stability. Cogent $\begin{array}{llll}\text { Economics } \quad \text { F } & 3(1), & 1-19 \text {. }\end{array}$ doi:https://doi.org/10.1080/23322039.2015.1111489

Akinleye, G. T., \& Faustina, A. T. (2017). Impact of corporate social responsibility on the profitability of multinational companies in Nigeria. Global Journal of Management and Business Research.

Akintoye, I. R. (2009). Sensitivity of Performance to Capital Structure. Banking \& Finance Letters, 1(2).

Ali, M., \& Puah, C.-H. (2018). Does bank size and funding risk effect banks' stability? A lesson from Pakistan. Global Business Review, 19(5), 1166-1186.

Arellano, M. (2002). Sargan's intrumental variables estimation and the generalized method of moments. Journal of Business \& Economic Statistics, 20(4), 450-459. doi:https://doi.org/10.1198/073500102288618595

Arellano, M., \& Bover, O. (1995). Another look at the instrumental variable estimation of error-components models. Journal of econometrics, 68(1), 29-51. doi:https://doi.org/10.1016/0304-4076(94)01642-D

Athanasoglou, P. P., Brissimis, S. N., \& Delis, M. D. (2008). Bank-specific, industry-specific and macroeconomic determinants of bank profitability. Journal of international financial Markets, Institutions and Money, 18(2), 121-136. doi:https://doi.org/10.1016/j.intfin.2006.07.001

Autio, E. (2018). Creative Tension: The Significance of Ben Oviatt's and Patricia McDougall's Article 'Toward a Theory of International New Ventures'. International Entrepreneurship, 59-81. doi:https://doi.org/10.1057/palgrave.jibs.8400117

Batir, T. E., Volkman, D. A., \& Gungor, B. (2017). Determinants of bank efficiency in Turkey: Participation banks versus conventional banks. Borsa Istanbul Review, 17(2), 86-96. doi:https://doi.org/10.1016/j.bir.2017.02.003

Berger, A. N., \& Humphrey, D. B. (1994). Bank scale economies, mergers, concentration, and efficiency: The US experience. In: Citeseer.

Bhagat, S., \& Bolton, B. (2008). Corporate governance and firm performance. Journal of corporate finance, 14(3), 257-273. doi:https://doi.org/10.1016/j.jcorpfin.2008.03.006

Bikker, J. A., \& Hu, H. (2002). Cyclical patterns in profits, provisioning and lending of banks and procyclicality of the new Basel capital requirements. PSL Quarterly Review, 55(221), 143-175. doi:https://doi.org/10.13133/2037-3643/9907 
Bond, S. R. (2002). Dynamic panel data models: a guide to micro data methods and practice. Portuguese economic journal, 1(2), 141-162. doi:https://doi.org/10.1007/s10258-002-0009-9

Bourke, P. (1989). Concentration and other determinants of bank profitability in Europe, North America and Australia. Journal of Banking \& Finance, 13(1), 65-79. doi:https://doi.org/10.1016/0378-4266(89)90020-4

Bowen, H. R., \& Johnson, F. E. (1953). Social responsibility of the businessman. New York: Harper.

Bucevska, V., \& Hadzi Misheva, B. (2017). The determinants of profitability in the banking industry: Empirical research on selected Balkan countries. Eastern European Economics, 55(2), 146-167. doi:https://doi.org/10.1080/00128775.2016.1260473

Chun, H., Kim, J.-W., Morck, R., \& Yeung, B. (2008). Creative destruction and firm-specific performance heterogeneity. Journal of Financial Economics, 89(1), 109-135. doi:https://doi.org/10.1016/j.jfineco.2007.06.005

Claver, E., Molina, J., \& Tarí, J. (2002). Firm and Industry Effects on Firm Profitability:: a Spanish Empirical Analysis. European Management Journal, 20(3), 321-328. doi:https://doi.org/10.1016/S0263-2373(02)00048-8

Clifford, P., \& Evans, R. (1997). Non-executive directors: a question of independence. Corporate Governance: An International Review, 5(4), 224-231. doi:https://doi.org/10.1111/1467-8683.00064

Curran, J., Jarvis, R., Blackburn, R. A., \& Black, S. (1993). Networks and small firms: constructs, methodological strategies and some findings. International Small Business Journal, 11(2), 13-25. doi:https://doi.org/10.1177/026624269301100202

Demirgüç-Kunt, A., \& Huizinga, H. (1999). Determinants of commercial bank interest margins and profitability: some international evidence. The World Bank Economic Review, 13(2), 379-408. doi:https://doi.org/10.1093/wber/13.2.379

Derbali, A. (2014). Determinants of performance of insurance companies in Tunisia: the case of life insurance. International Journal of Innovation and Applied Studies, 6(1), 90-96.

Dietrich, A., \& Wanzenried, G. (2011). Determinants of bank profitability before and during the crisis: Evidence from Switzerland. Journal of international financial Markets, Institutions and Money, 21(3), 307-327. doi:https://doi.org/10.1016/j.intfin.2010.11.002

Donaldson, T., \& Preston, L. E. (1995). The stakeholder theory of the corporation: Concepts, evidence, and implications. Academy of management Review, 20(1), 6591. doi:https://doi.org/10.5465/amr.1995.9503271992

Ducassy, I. (2013). Does corporate social responsibility pay off in times of crisis? An alternate perspective on the relationship between financial and corporate social performance. Corporate Social Responsibility and Environmental Management, 20(3), 157-167. doi:https://doi.org/10.1002/csr.1282

Eccles, R., Ioannou, I., \& Serafeim, G. (2012). Is sustainability now the key to corporate success. The Guardian.

Freeman, R. E. (2010). Strategic management: A stakeholder approach: Cambridge university press.

Goddard, J., Liu, H., Molyneux, P., \& Wilson, J. O. (2011). The persistence of bank profit. Journal of Banking \& Finance, 35(11), 2881-2890. doi:https://doi.org/10.1016/j.jbankfin.2011.03.015

Goddard, J., Liu, H., Molyneux, P., \& Wilson, J. O. (2013). Do bank profits converge? European Financial Management, 19(2), 345-365. doi:https://doi.org/10.1111/j.1468-036X.2010.00578.x

Haniffa, R., \& Hudaib, M. (2007). Exploring the ethical identity of Islamic banks via communication in annual reports. Journal of business Ethics, 76(1), 97-116. doi:https://doi.org/10.1007/s10551-006-9272-5

Hansen, L. P. (1982). Large sample properties of generalized method of moments estimators. Econometrica: Journal of the econometric society, 50(4), 1029-1054.

Ito, K., \& Fukao, K. (2006). Determinants of the Profitability of Japanese Manufacturing Affiliates in China and Other Regions: Does Localization of Procurement, Sales, and Management Matter? Retrieved from

Jensen, M. C., \& Meckling, W. H. (1976). Theory of the firm: Managerial behavior, agency costs and ownership structure. Journal of Financial Economics, 3(4), 305-360. doi:https://doi.org/10.1016/0304-405X(76)90026-X 
Jones, C. I. (1995). R \& D-based models of economic growth. Journal of political Economy, 103(4), 759-784.

Kiran, S., Kakakhel, S. J., \& Shaheen, F. (2015). Corporate social responsibility and firm profitability: A case of oil and gas sector of Pakistan. City University Research Journal, 5(1), 110-119.

Kludacz-Alessandri, M., \& Cygańska, M. (2021). Corporate Social Responsibility and Financial Performance among Energy Sector Companies. Energies, 14(19), 1-16. doi:https://doi.org/10.3390/en14196068

Kohlscheen, E., Murcia Pabón, A., \& Contreras, J. (2018). Determinants of bank profitability in emerging markets.

KPMG. (2021). Pakistan banking Perspective. Retrieved from https://home.kpmg/pk/en/home/insights/2021/06/pakistan-banking-perspective-

2021.html

Le, M., Hoang, V.-N., Wilson, C., \& Ngo, T. (2020). Risk-adjusted efficiency and bank size in a developing economy: an analysis of Vietnamese banks. Journal of Economic Studies, 47(2), 386-404. doi:https://doi.org/10.1108/JES-12-2018-0425

Levrau, A., \& van Den Berghe, L. (2007). Corporate governance and board effectiveness: Beyond formalism. Vlerick Business School, 3, 40.

Levy, R. (1999). Give and take: A candid account of corporate philanthropy: Harvard Business Press.

Lin, C.-S., Chang, R.-Y., \& Dang, V. T. (2015). An integrated model to explain how corporate social responsibility affects corporate financial performance. Sustainability, 7(7), 8292-8311. doi:https://doi.org/10.3390/su7078292

Liu, H., \& Wilson, J. O. (2010). The profitability of banks in Japan. Applied Financial Economics, 20(24), 1851-1866. doi:https://doi.org/10.1080/09603107.2010.526577

Maali, B., Casson, P., \& Napier, C. (2006). Social reporting by Islamic banks. Abacus, 42(2), 266-289. doi:https://doi.org/10.1111/j.1467-6281.2006.00200.x

Mallinguh, E., Wasike, C., \& Zoltan, Z. (2020). The business sector, firm age, and performance: The mediating role of foreign ownership and financial leverage. International Journal of Financial Studies, 8(4), 79. doi:https://doi.org/10.3390/ijfs8040079

Margolis, J. D., \& Walsh, J. P. (2001). Misery loves companies: whither social initiatives by business? : Citeseer.

McGuire, J. B., Sundgren, A., \& Schneeweis, T. (1988). Corporate social responsibility and firm financial performance. Academy of management Journal, 31(4), 854-872. doi:https://doi.org/10.5465/256342

McWilliams, A., Siegel, D. S., \& Wright, P. M. (2006). Corporate social responsibility: Strategic implications. Journal of management studies, 43(1), 1-18. doi:https://doi.org/10.1111/j.1467-6486.2006.00580.x

Mehari, D., \& Aemiro, T. (2013). Firm specific factors that determine insurance companies' performance in Ethiopia. European scientific journal, 9(10), 245-255.

Min, M., Desmoulins-Lebeault, F., \& Esposito, M. (2017). Should pharmaceutical companies engage in corporate social responsibility? Journal of Management Development, 36(1), 58-70. doi:https://doi.org/10.1108/JMD-09-2014-0103

Molyneux, P., \& Thornton, J. (1992). Determinants of European bank profitability: A note. Journal of Banking \& Finance, 16(6), 1173-1178. doi:https://doi.org/10.1016/03784266(92)90065-8

Moore, G. (2001). Corporate social and financial performance: An investigation in the UK supermarket industry. Journal of business Ethics, 34(3), 299-315. doi:https://doi.org/10.1023/A:1012537016969

Orlitzky, M., Schmidt, F. L., \& Rynes, S. L. (2003). Corporate social and financial performance: A meta-analysis. Organization studies, 24(3), 403-441. doi:https://doi.org/10.1177/0170840603024003910

Pasiouras, F., \& Kosmidou, K. (2007). Factors influencing the profitability of domestic and foreign commercial banks in the European Union. Research in International Business and Finance, 21(2), 222-237. doi: https://doi.org/10.1016/j.ribaf.2006.03.007

Peloza, J. (2009). The challenge of measuring financial impacts from investments in corporate social performance. Journal of Management, 35(6), 1518-1541. doi:https://doi.org/10.1177/0149206309335188 
Pham, T. T., Dao, L. K. O., \& Nguyen, V. C. (2021). The determinants of bank's stability: a system GMM panel analysis. Cogent Business \& Management, 8(1), 1963390. doi:https://doi.org/10.1080/23311975.2021.1963390

Phan, H. T., Anwar, S., Alexander, W. R. J., \& Phan, H. T. M. (2019). Competition, efficiency and stability: An empirical study of East Asian commercial banks. The North American Journal of Economics and Finance, 50, 100990. doi:https://doi.org/10.1016/j.najef.2019.100990

Pushner, G. M. (1995). Equity ownership structure, leverage, and productivity: Empirical evidence from Japan. Pacific-Basin Finance Journal, 3(2-3), 241-255. doi:https://doi.org/10.1016/0927-538X(95)00003-4

Resmi, S. I., Begum, N. N., \& Hassan, M. M. (2018). Impact of CSR on firm's financial performance: a study on some selected agribusiness industries of Bangladesh. American Journal of Economics, Finance and Management, 4(3), 74-85.

SBP. (Various Issues). Financial Statements Analysis of Financial Sector, Karachi.

Singh, S. K., Chen, J., Del Giudice, M., \& El-Kassar, A.-N. (2019). Environmental ethics, environmental performance, and competitive advantage: role of environmental training. Technological Forecasting and Social Change, 146, 203-211. doi:https://doi.org/10.1016/j.techfore.2019.05.032

Sinha, P., \& Sharma, S. (2016). Determinants of bank profits and its persistence in Indian Banks: a study in a dynamic panel data framework. International Journal of System Assurance Engineering and Management, 7(1), 35-46. doi:https://doi.org/10.1007/s13198-015-0388-9

Tan, Y. (2016). The impacts of risk and competition on bank profitability in China. Journal of international financial Markets, Institutions and Money, 40, 85-110. doi:https://doi.org/10.1016/j.intfin.2015.09.003

Tan, Y., \& Floros, C. (2012). Bank profitability and GDP growth in China: a note. Journal of Chinese Economic and Business Studies, 10(3), 267-273. doi:https://doi.org/10.1080/14765284.2012.703541

Van Ees, H., van der Laan, G., \& Postma, T. J. (2008). Effective board behavior in the Netherlands. European Management Journal, 26(2), 84-93. doi:https://doi.org/10.1016/j.emj.2008.01.002

Wagner, M. (2010). Corporate social performance and innovation with high social benefits: A quantitative analysis. Journal of business Ethics, 94(4), 581-594. doi:https://doi.org/10.1007/s10551-009-0339-y

WDI. (2018). World Development Indicators, The World Bank: Washington DC.

Weber, M. (2008). The business case for corporate social responsibility: A company-level measurement approach for CSR. European Management Journal, 26(4), 247-261. doi:https://doi.org/10.1016/j.emj.2008.01.006

Weill, L. (2008). Leverage and corporate performance: does institutional environment matter? Small Business Economics, 30(3), 251-265. doi:https://doi.org/10.1007/s11187-006-9045-7

Williams, B. (2007). Factors determining net interest margins in Australia: domestic and foreign banks. Financial Markets, Institutions \& Instruments, 16(3), 145-165. doi:https://doi.org/10.1111/j.1468-0416.2007.00122.x

Wu, L., Shao, Z., Yang, C., Ding, T., \& Zhang, W. (2020). The impact of CSR and financial distress on financial performance-evidence from Chinese listed companies of the manufacturing industry. Sustainability, 12(17), 1-19. doi:https://doi.org/10.3390/su12176799

Xu, B., \& Zeng, T. (2016). Profitability, state ownership, tax reporting and corporate social responsibility: evidence from Chinese listed firms. Social Responsibility Journal, 12(1), 23-31. doi:https://doi.org/10.1108/SRJ-06-2014-0076

Yao, H., Haris, M., \& Tariq, G. (2018). Profitability determinants of financial institutions: evidence from banks in Pakistan. International Journal of Financial Studies, 6(2), 128. doi:https://doi.org/10.3390/ijfs6020053

Yazdanfar, D. (2013). Profitability determinants among micro firms: evidence from Swedish data. International Journal of Managerial Finance, 9(2), 151-160. doi:https://doi.org/10.1108/17439131311307565

Zeitun, R., \& Tian, G. G. (2014). Capital structure and corporate performance: evidence from Jordan. Australasian Accounting Business \& Finance Journal, Forthcoming. 